\title{
Historical and future drought impacts in the Pacific islands and atolls
}

\author{
Viliamu lese $^{1} \cdot$ Anthony S. Kiem $^{2}$ (D) Azarel Mariner ${ }^{3} \cdot$ Philip Malsale $^{3}$. \\ Tile Tofaeono $^{3}$ - Dewi G.C. Kirono ${ }^{4}$ (D) $\cdot$ Vanessa Round $^{4}$ (D) Craig Heady $^{4}$ (D) \\ Robson Tigona ${ }^{5} \cdot$ Filipe Veisa $^{5} \cdot$ Kisolel Posanau $^{6}$ • Faapisa Aiono ${ }^{7}$ - Alick Haruhiru ${ }^{8}$. \\ Arieta Daphne ${ }^{9}$. Vaiola Vainikolo ${ }^{10} \cdot$ Nikotemo lona $^{11}$
}

Received: 25 August 2020 / Accepted: 26 April 2021 / Published online: 18 May 2021

(C) The Author(s) 2021

\begin{abstract}
Drought is known as a "creeping disaster" because drought impacts are usually noticed months or years after a drought begins. In the Pacific Island Countries and Territories (PICTs), there is almost no ability to tell when a drought will begin or end, especially for droughts other than meteorological droughts. Monitoring, forecasting and managing drought in the PICTs is complex due to the variety of different ways droughts occur, and the diverse direct and indirect causes and consequences of drought, across the PICT region. For example, the impacts of drought across the PICTs vary significantly depending on (i) the type of drought (e.g. meteorological drought or agricultural drought); (ii) the location (e.g. high islands versus atolls); (iii) socioeconomic conditions in the location affected by drought; and (iv) cultural attitudes towards the causes of drought (e.g. a punishment from God versus a natural process that is potentially predictable and something that can be managed). This paper summarises what is known and unknown about drought impacts in the PICTs and provides recommendations to guide future research and investment towards minimising the negative impacts of droughts when they inevitably occur in the PICTs.
\end{abstract}

Keywords Water security $\cdot$ Adaptation $\cdot$ Climate variability $\cdot$ Climate change $\cdot$ Agriculture

Viliamu Iese

viliamu.iese@usp.ac.fj

Anthony S. Kiem

Anthony.Kiem@newcastle.edu.au

Extended author information available on the last page of the article 


\section{Introduction}

Water, water, everywhere, And all the boards did shrink; Water, water, everywhere, Nor any drop to drink. (The rhyme of the ancient mariner)

It is a cruel irony that, though surrounded by the vast expanse of the largest ocean on the planet, the islands and atolls of Micronesia can run out of drinkable water. (Thompson 2016)

The World Economic Forum estimates that drought costs \$US6-8 billion a year globally due to losses in agriculture and related businesses alone - this does not include non-agricultural economic costs or non-economic costs (e.g. impacts on mental health and well-being, changes to community/culture, environmental damage) (Below et al. 2007; Botterill and Cockfield 2013). Multidecadal climate variability (e.g. Kiem and Franks 2004; Vance et al. 2015; McGree et al. 2016), as well as projected impacts of anthropogenic climate change (e.g. IPCC 2013; Van Loon et al. 2016a, 2016b), also means that drought will remain a key concern into the future.

Despite their significance, and existing literature on drought, droughts are still poorly understood (e.g. van Dijk et al. 2013; Blauhut et al. 2015; Kiem et al. 2016). This is because the cause-effect relationships between drought and the variety of factors that contribute to drought are complicated and not satisfactorily monitored, modelled or predicted. Also lacking, especially for Pacific islands and atolls (Fig. 1), is information on the direct and indirect impacts of the different types of drought and how these vary across locations, communities and industries. These two knowledge gaps make it challenging to develop robust drought mitigation and management strategies.

Pacific Island Countries and Territories (PICTs) are heterogeneous. The Pacific region comprises 28 countries, which are divided into the sub-regions of Micronesia, Melanesia and Polynesia (Fig. 1), and these countries contain $\sim 20,000$ islands and atolls that are scattered across the Pacific Ocean. The PICTs cover 46\% of Earth's water surface (Goldberg 2018) and are home to $\sim 10$ million people (Sisifa et al. 2016). The larger Melanesian countries of Papua New Guinea (PNG), Fiji, New Caledonia, Solomon Islands and Vanuatu represent $90 \%$ of the total Pacific Island population and $85 \%$ of the total land area. The Pacific region also includes some of the smallest, remote, scattered and lowest elevation countries in the world (e.g. the land area of Tuvalu is only $26 \mathrm{~km}^{2}$ with the highest point only $5 \mathrm{~m}$ above sea level (Sisifa et al. 2016; Wairiu et al. 2012)). Heterogeneity exists both between and within PICTs. The higher islands have rivers, streams and groundwater. In contrast, the smallest islands and atolls rely exclusively on rainwater and shallow groundwater in lenses sometimes sitting above saline water (UNESCAP 2007) for drinking, cooking, washing and other socioeconomic functions (Sisifa et al. 2016). The vulnerability of PICTs to drought therefore depends on geographic location and the type of island. This paper includes case studies of impacts representing high islands (PNG, Fiji, Vanuatu, Samoa, Tonga) and atolls (Tuvalu and Republic of the Marshall Islands (RMI)) across the three Pacific sub-regions (i.e. Micronesia, Melanesia and Polynesia).

This paper (i) summarises the causes of meteorological and agricultural droughts in the PICTs, (ii) identifies how drought impacts Pacific people, with particular focus on better understanding drought impacts in high islands versus atolls, and (iii) quantifies how drought is projected to change in the future for Pacific islands and atolls. The paper concludes by highlighting the major uncertainties and challenges relating to drought management in the Pacific along with some recommendations for how to address these challenges. 


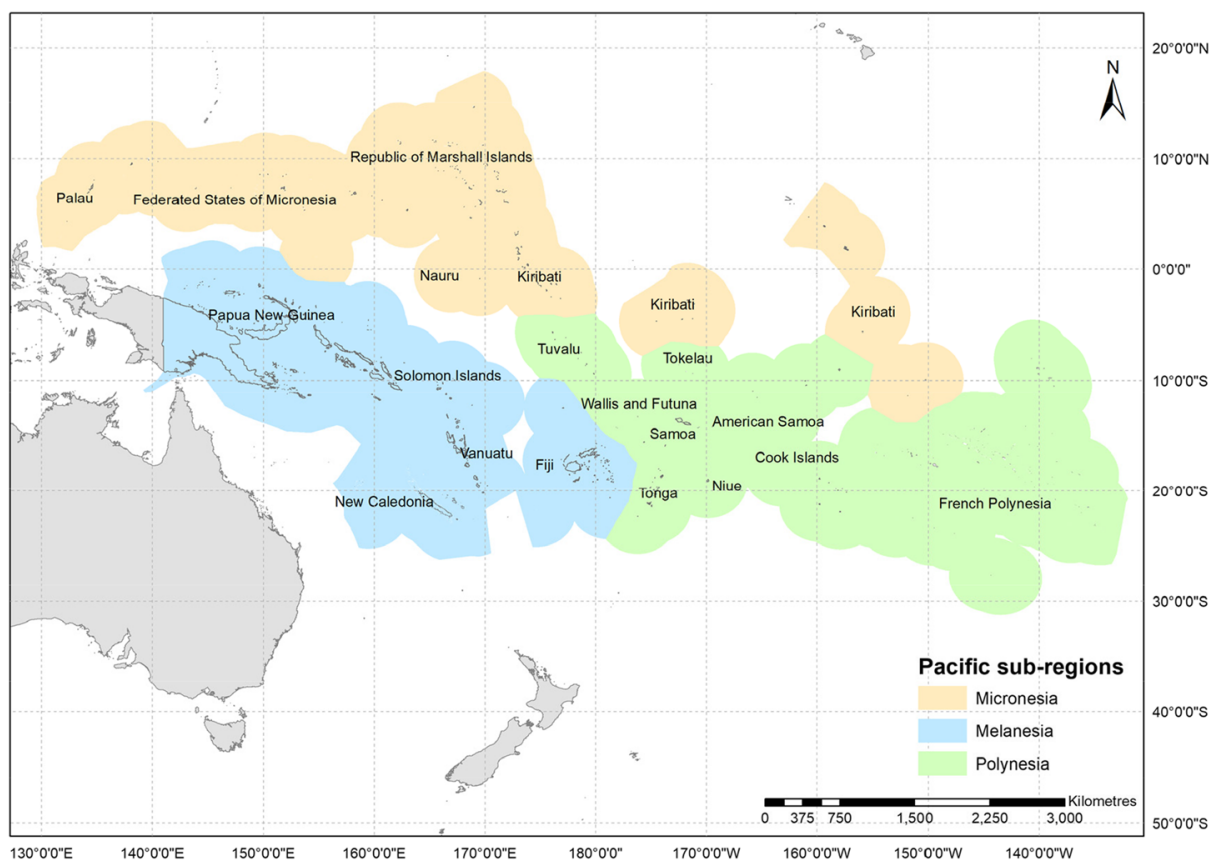

Fig. 1 Pacific islands and atolls (Source: Peter McDonald (SPREP))

\section{Defining drought}

Unlike other natural hazards which have more graphic, immediate and measurable impacts (e.g. floods, tropical cyclones, coastal inundation events), droughts are considered to be slowonset hazards, are spatially extensive, can persist for more than a year and often go unnoticed until wide-spread water, food, energy, economic, health or environmental impacts are triggered (e.g. Wilhite et al. 2007; Van Loon 2015; Kiem et al. 2016). By the time a drought is identified, it is usually already well underway, remediation costs are mounting and the opportunity for proactive mitigation or adaptation is gone. Complicating this are uncertainties or knowledge gaps around defining, monitoring and forecasting drought (including the termination of drought) (e.g. Parry et al. 2016) and for deriving accurate and practically useful quantification of drought likelihoods and consequences.

Droughts have a wide range of cascading impacts that may be exacerbated by different drought aspects or other external factors like land use change, increase in water demand and change in policies to name a few (e.g. van Dijk et al. 2013). Previous research (e.g. Peterson et al. 2013; Lloyd-Hughes 2014; Masih et al. 2014; Garner et al. 2015; Van Loon 2015; Kiem et al. 2016) has increased understanding into drought and-based on the acknowledgement that drought is more than a rainfall deficiency_led to various drought definitions and categories. This paper focuses only on meterological drought and agricultural drought. This is because (i) the Pacific atolls have a fragile freshwater resource base that can be quickly depleted when there is a lack of rainfall (i.e. meteorological drought) (Barnett and Campbell 2010) and (ii) the larger/higher Pacific islands have a heavy reliance on agricultural productivity (Barnett 2011; Iese et al. 2018). While the focus here is on meteorological and agricultural drought, it is important to recognise that other types of drought are also important 
in the PICTs (e.g. hydrological droughts are important in Fiji, and socioeconomic droughts are important everywhere).

\section{Historical drought in Pacific Island Countries and Territories}

\subsection{What does the literature say about historical droughts in the PICTs?}

Drought is a recurrent climate feature in the Australia-Pacific region (Nunn 2007; Vance et al. 2015). Kiem et al. (2016) document the factors that cause (or contribute to) drought in Australia and most of the influential factors for eastern Australia (e.g. El Niño/Southern Oscillation (ENSO) and the location/phase of the Intertropical Convergence Zone (ITCZ) and the South Pacific Convergence Zone (SPCZ)) and also apply to the wider Pacific region (e.g. McGree et al. 2016).

There are anecdotal accounts of pre-colonial droughts that caused famines in the PICTs (Roberts 1958; Allen 2015; Iese et al. 2018). Early European settlers also documented the occurrence of droughts in the PICTs (McGree et al. 2016). However, despite the long history of drought in the PICTs, long-term, objective documentation of droughts in PICTs is limited due to the lack of long-term (i.e. 100 years or more) hydroclimatic records coupled with limited understanding into the causes and impacts of drought at the PICT scale (McGree et al. 2016). This is also evident in the limited information on historical droughts included in the Pacific Climate Change Science Programme climate assessment of PICTs in 2011 and 2013there is information on dry and wet seasonal variations of rainfall but minimal details on droughts (Australian Bureau of Meteorology and CSIRO 2014; CSIRO et al. 2015).

McGree et al. (2016) attempted to address these knowledge gaps when they analysed meteorological drought frequency, duration and magnitude using precipitation records from 21 PICTs for the period 1951 to 2010. McGree et al. (2016) found that the frequency, duration and magnitude of meteorological droughts for PICTs was greater during the 1981-2010 period than the 1951-1980 period. This finding confirmed the perception of Pacific Islanders that they are experiencing more frequent and intense droughts. However, McGree et al. (2016) explain that this is mostly due to interannual to decadal climate variability given the lack of statistically significant trends in drought frequency, duration and magnitude over the 19512010 period. Deo (2011) also reported that drought duration and severity was non-uniform in Fiji between 1949 and 2008, especially for western and northern Fiji where rainfall deficiencies for the period 1969-1988 led to a dramatic increase in moderate and severe droughts and a "net shift towards drier conditions since the 1950s". This reinforces recommendations made in drought studies from other parts of the world (e.g. Van Loon 2015; Kiem et al. 2016) for the development of an agreed set of drought definitions/categories that clearly differentiates drought from long-term changes in aridity and water scarcity and that captures attributes of drought such as start, duration, magnitude and spatial extent.

Despite limited studies looking at trends in the occurrence and intensity of droughts in PICTs, the drivers of meteorological droughts in the Pacific are well researched. ENSO is the primary driver of interannual variability and Interdecadal Pacific Oscillation (IPO) and Pacific Decadal Oscillation (PDO) the primary driver of multidecadal hydroclimatic variability in the Pacific Islands region (e.g. Tigona and de Freitas 2012; Australian Bureau of Meteorology and CSIRO 2014; Murphy et al. 2014; Salinger et al. 2014). Previous studies have also summarised the influence of ENSO and IPO/PDO, and their interactions with other climate 
drivers (e.g. the location/phase of the ITCZ, SPCZ, West Pacific Warm Pool (WPWP)), on meteorological drought in the PICTs (e.g. Cai et al. 2012; Liberto 2016; McGree et al. 2016; Howes et al. 2018; Paeniu 2018; Keremama et al. 2019; Chand 2020).

While insights exist into the relationship between Pacific climate drivers and historical droughts in PICTs, it is unclear how climate change is influencing, and will potentially continue to influence, Pacific climate drivers and rainfall in PICTs. Time spent in drought is projected to decrease slightly or remain the same for most PICTs. However, there are regional nuances and also low confidence in projections of how climate change may affect spatial and temporal rainfall variability (e.g. IPCC 2013), and therefore, drought frequency, duration and spatial extent across the PICTs (Lefale et al. 2018).

\subsection{What do the people say about historical droughts in the PICTs?}

National meteorological services were consulted to (1) select drought events where the impacts were severe and affected local communities; (2) describe the characteristics of selected droughts (e.g. drought duration, rainfall conditions); and (3) provide documentation on drought impacts (e.g. duration, rainfall totals, and loss/damage assessments). Drought events identified were further profiled using the rainfall deficiency monitoring function of the Seasonal Climate Outlook for Pacific Island Countries (SCOPIC, https://www.pacificmet. net/products-and-services/seasonal-climate-outlooks-pacific-island-countries-scopic), which provides information on drought duration at selected stations, total rainfall during the drought and the ENSO phase the drought occurred in. The drought events associated with El Niño in 1982-1983, 1997-1998 and 2015-2016 for Fiji, Samoa, Vanuatu, PNG, Tonga and Federated States of Micronesia (FSM) and La Niña in 2010-2012 were selected. A narrative analysis (i.e. a synthesis of anecdotal and qualitative information provided by officers from the national meteorological services) was conducted to illustrate the exposure of PICTs to droughts as well as the adverse effects on vulnerable communities.

ENSO, and associated drought conditions, affect many PICTs simultaneously. Table 1 shows that droughts associated with El Niño events that occurred in 1982-1983, 1997-1998 and 2015-2016 affected PICTs scattered in central-western regions and in both north and south Pacific sub-regions. Although they had different intensities, the duration of meteorological droughts ranged from 5 to 27 months in 1982-1983; 5 to 13 months in 1997-1998 and 2 to 23 months in 2015-2016.

Individual PICTs cover large ocean areas, often comprising multiple islands that are spatially scattered. Therefore, the occurrence and intensity of droughts differ within countries relative to the spatial impact regions of the rainfall drivers mentioned above-ENSO, SPCZ, ITCZ, IPO/PDO and the Walker Circulation. For example, as shown in Table 1, the drought of 1982 in Vanuatu started in Pekoa (North Vanuatu) a year earlier than Port Vila (Central Vanuatu) and 16 months before Southern Vanuatu. Overall, Vanuatu government had to respond to 27 months of drought conditions. Another example was in Tuvalu during the La Niña of 2011-2012 where Funafuti (Central Tuvalu) experienced the drought for 1 year (December 2010-December 2011) while Niulakita (Southern Tuvalu) experienced three droughts between February 2010 and June 2013. Tuvalu communities and government suffered the impacts of drought for almost 3 years.

Table 1 shows information on meteorological droughts for the PICTs, with detailed information on drought duration, magnitude and timing. In the PICTs, and elsewhere in the world, it is difficult to know when agricultural droughts start and end (e.g. Kiem et al. 2016; 


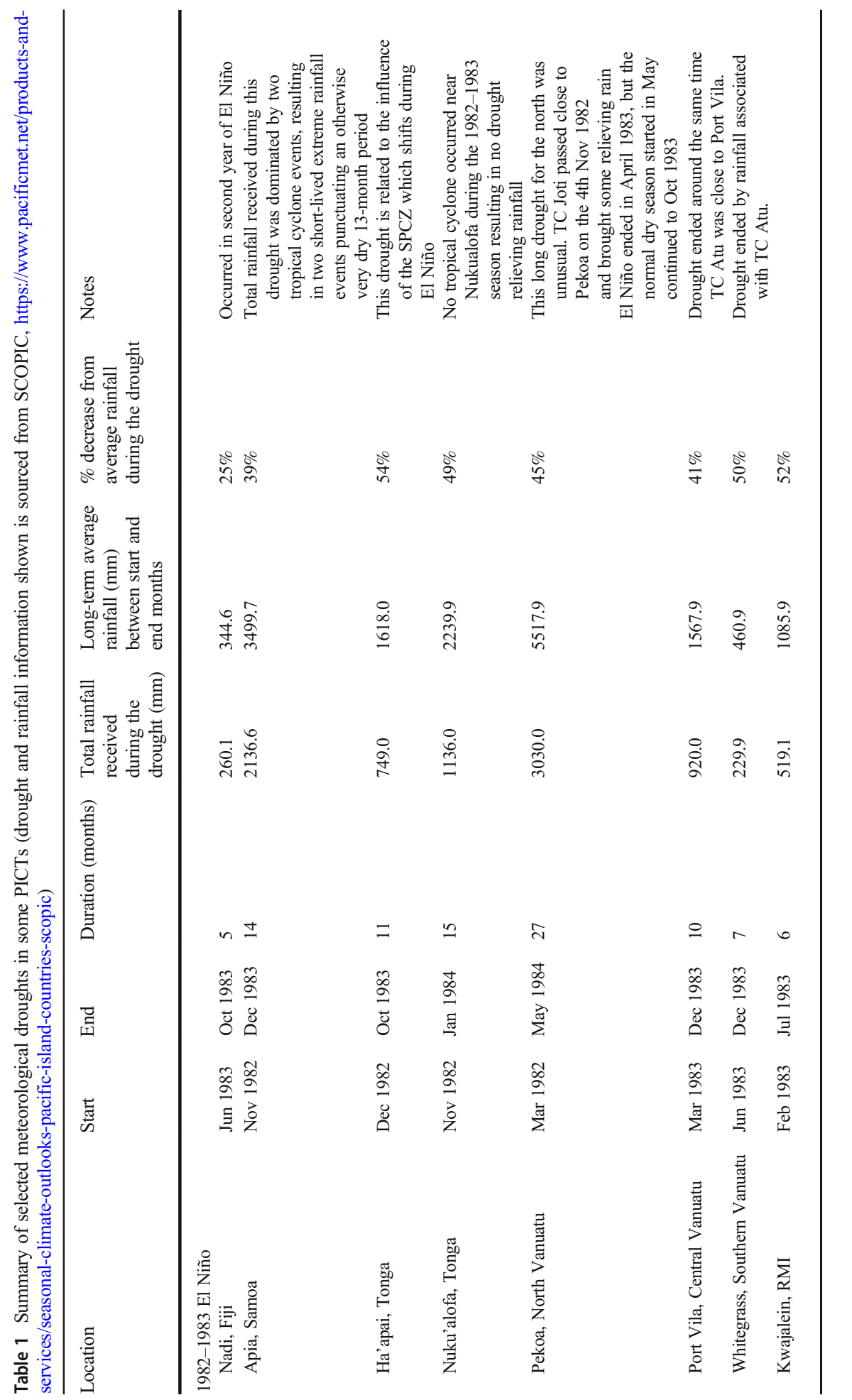




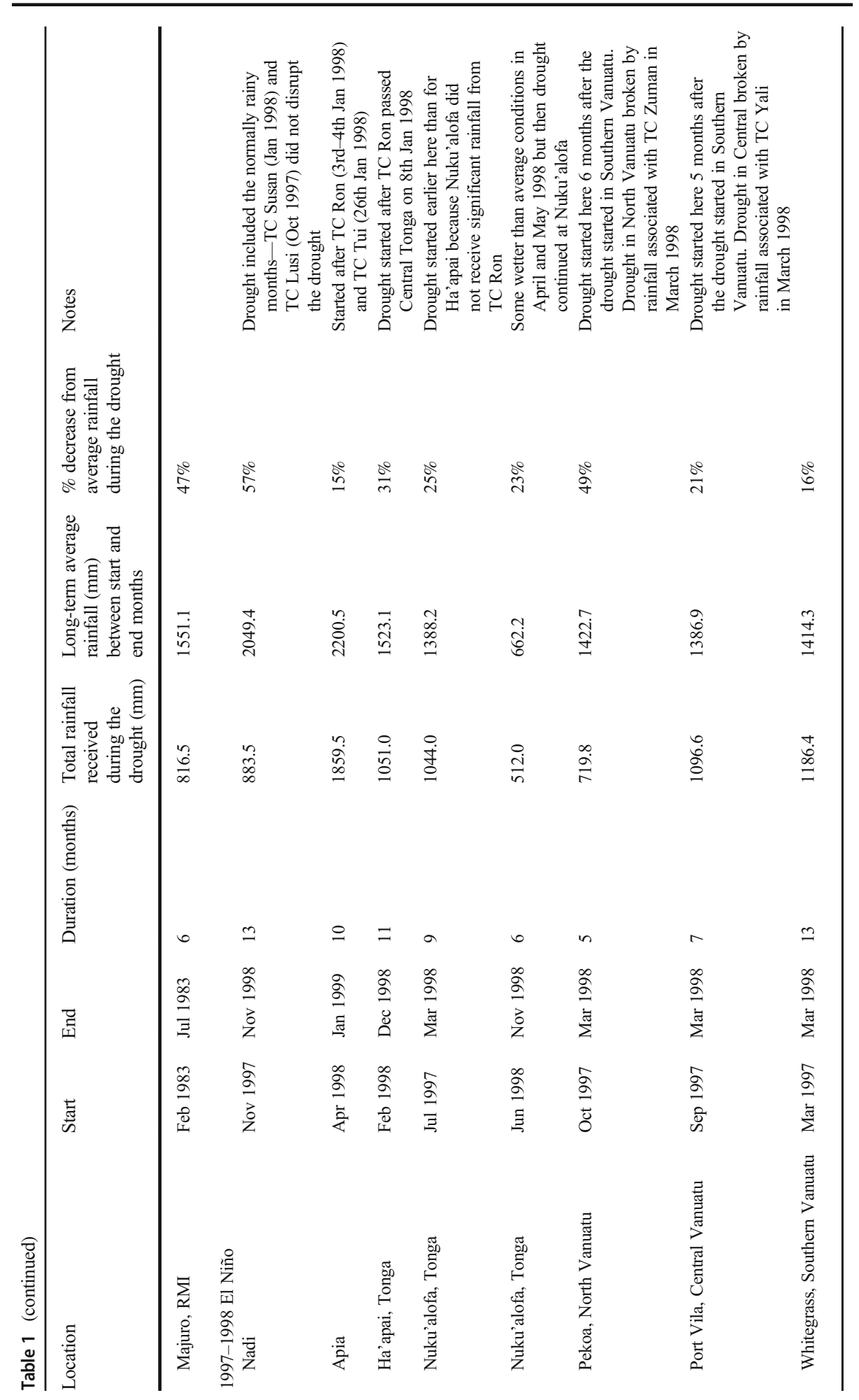




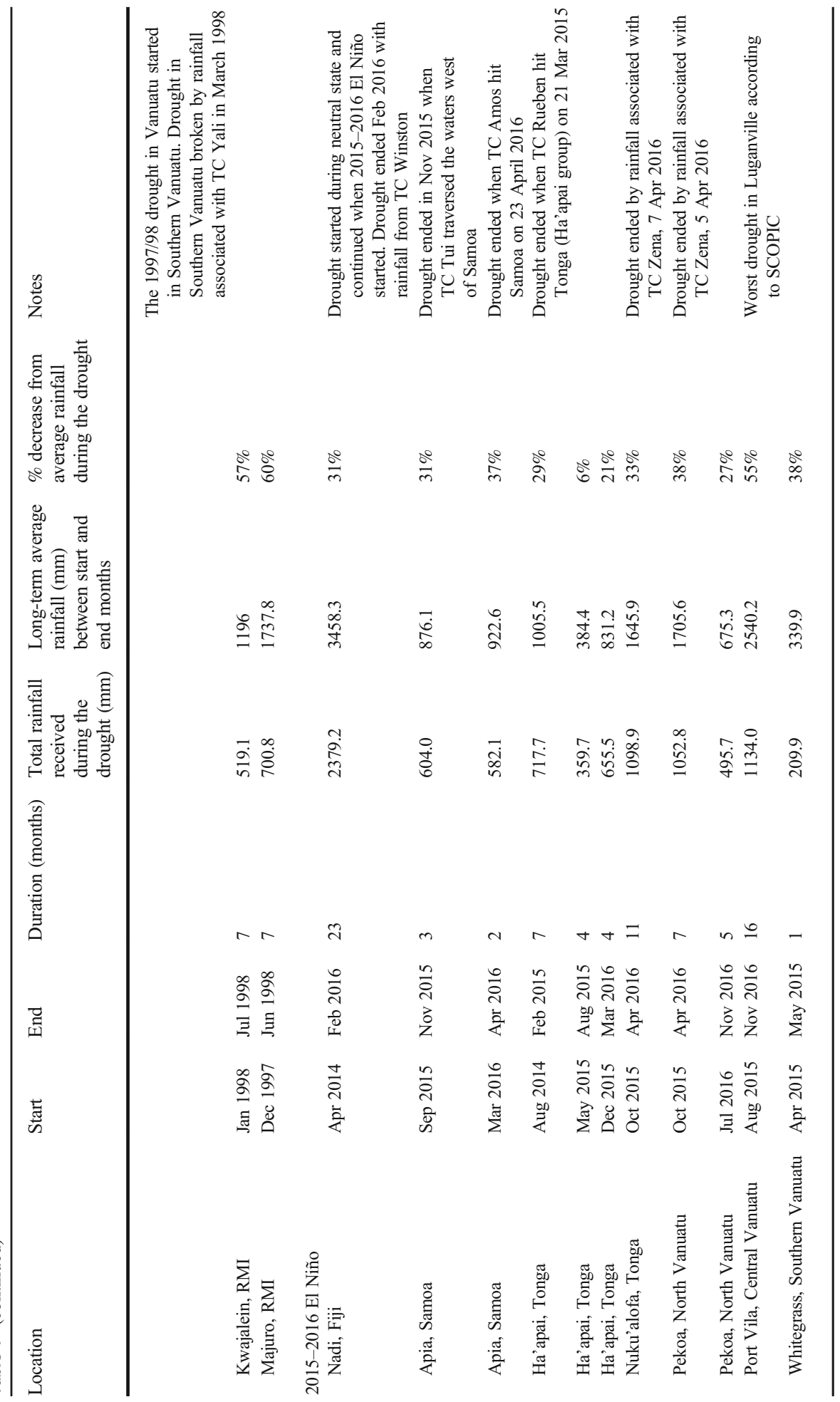




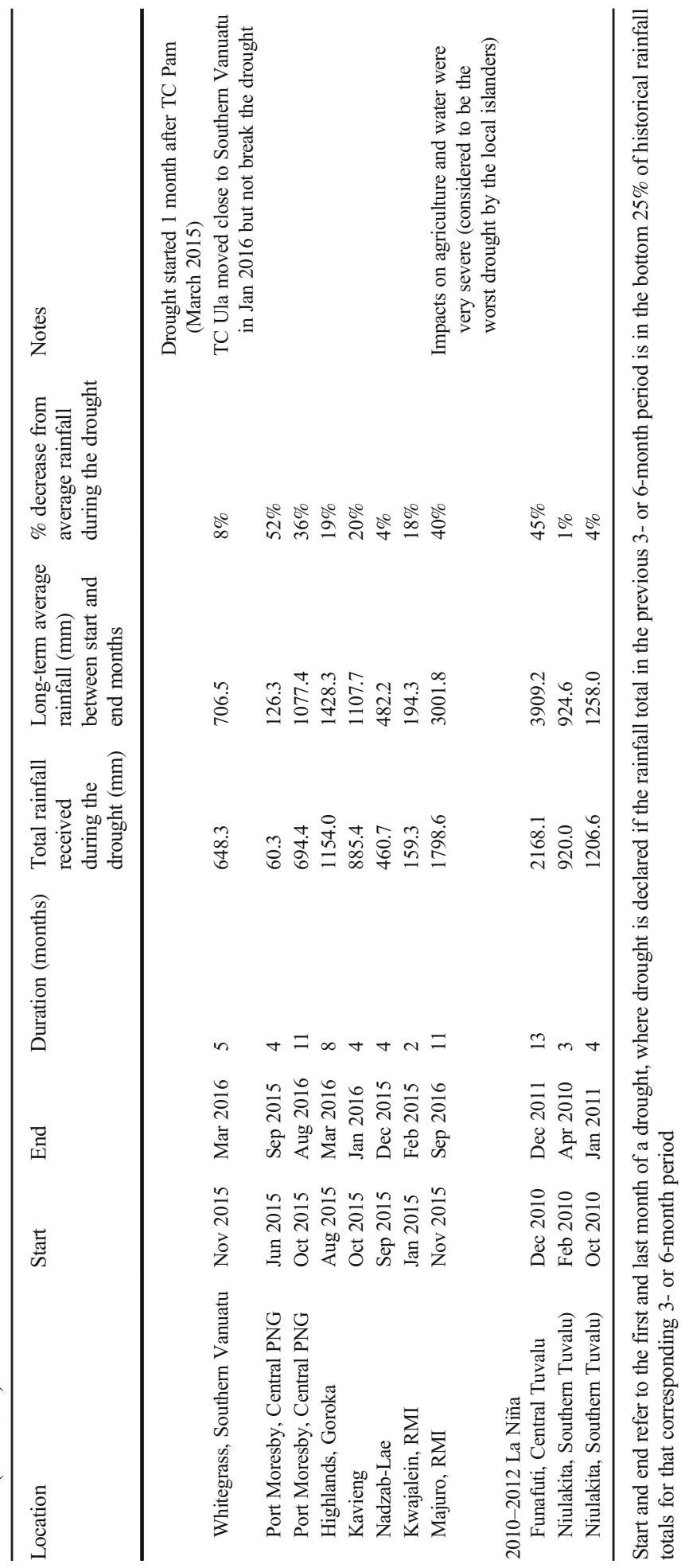


Gibson et al. 2020; Askarimarnani et al. 2021). This makes it difficult to plan drought emergency relief interventions as evident in 2015-2016 in Fiji-without data the Food Security and Agriculture Cluster found it hard to know where intense agricultural drought was occurring and how many farmers were affected. This has often led to delays in drought response planning and implementation in the agriculture sector.

\subsection{Observed impacts of droughts in the PICTs}

\subsubsection{Vanuatu}

The impacts of droughts in PICTs are severe and diverse. As Table 1 shows, the El Niño induced 2015-2016 drought that affected many PICTs. In Vanuatu the people rely on rainwater harvesting systems and wells for consumption, as there are no rivers. During the drought, most water tanks in Vanuatu were empty or had only small amounts of heavily contaminated water at the bottom of the tank. Villagers from $\sim 20 \%$ of households walked for long distances (more than $30 \mathrm{~min}$ ) for washing and showering and to collect water for cooking and drinking (OCHA 2015). Households with money paid about \$US12/trip to hire a truck to fetch water for drinking and cooking. Primary schools were operational for half-day classes only because students walked in the afternoon to bath in the sea due to water shortages (Marango 2015; Roberts 2015). The 2015-2016 drought which followed Category 5 TC Pam destroyed vegetation across Vanuatu, and lack of foliage worsened the impacts of the drought on soils and crops, reducing food security. Savage et al. (2021) reported that all yams and taro died forcing 90,000 people (about $30 \%$ of the total population) to rely on food aid which was often spent on expensive food that had low nutritional value. Food shortages were particularly severe in the southern part of Vanuatu, especially Tanna Island, where lack of food contributed to the death of a child who consumed only nipatem (a root plant which is usually considered a weed but is consumed during periods where there is a shortage of food) for 4 days because root crops and vegetables did not grow (Willie 2015).

\subsubsection{PNG}

The 2015-16 drought also reduced food security in PNG. For areas with very high elevation ( 2200 to $2800 \mathrm{~m}$ ), the effects of the drought were compounded by the effects of frost on crops. The drought and frost affected $\sim 700,000$ people and $\sim 450,000$ people faced critical food shortages. Food shortages were concentrated in four ecological zones: (i) very high altitude areas (2200 to $2800 \mathrm{~m}$ ); (ii) the central highlands, inland and lowland areas in the Western Province; (iii) locations in South Fly and Middle Fly districts; and (iv) small and remote islands in the Milne Bay Province. Food shortages affected peoples' health and increased the death rate in some locations. People were relegated to eating unusual foods or famine foods in abnormally large quantities. The drought caused water shortages and forced many women and girls to walk long distances to obtain drinking water, often from sources that they would not normally use. Women reported experiencing increased harassment on the journey and at water collection points. The drought increased the workload of women as they were involved in collection of water from distant sources and reestablishment of gardens. Other social and health impacts were also reported (e.g. as stealing, high consumption of alcohol, increased incidences of gut and skin diseases) (Bourke et al. 2016; PNG National Disaster Centre 2016). 


\subsubsection{RMI}

The 2015-2016 El Niño triggered a severe drought that impacted the entire RMI chain, leading to a declaration of a state of emergency on 3rd February 2016. About $81 \%$ of the population of RMI experienced severely reduced access to water and extensive damages and losses of food crops. People conserved what little water they had for drinking and cooking at the expense of hygiene causing an increase in the spread of diseases like conjunctivitis. The following quote highlights the severity of the drought impacts on RMI and northern Pacific Islands:

Wells have become brackish or run dry; the rain barrels that perch on the corners of houses have little or no rainwater left in them. Water rationing is limited to a couple hours a day in some of the worst-hit communities, while expensive reverse-osmosis machines have been shipped out to the most far-flung atolls to make the seawater drinkable. Staple foods like breadfruit and bananas have shrivelled on the trees, inedible. (Thompson 2016)

\subsubsection{Tuvalu}

The Central Pacific has also experienced severe drought impacts (e.g. Paeniu 2018). For example, the prolonged drought that affected Tuvalu during the 2011-2012 La Niña (Table 1) led to severe water shortages and loss of crops critical for food security. The Government of Tuvalu declared a state of emergency on 28th September 2011 as the drought directly or indirectly affected the entire population of Tuvalu. Communal water supplies were rationed to as little as $2.1 \mathrm{~L} /$ person/day. In some islands, $61 \%$ of households relied solely on brackish well water for bathing, washing clothes and flushing toilets. Well water was tested and found not fit for human consumption. Four children and three adults were hospitalised for diarrhoea and vomiting in Nukulaelae during the drought (Sinclair et al. 2012). The limited crops that can grow in a hostile atoll environment - such as coconut, breadfruit, bananas and giant swamp taro (pulaka)—wilted and died or became inedible (Tekinene 2014). Giant swamp taro, which is a core crop for socio-cultural and food security in atoll islands and is planted in excavated pits reaching the water table, showed a high degree of stress caused by exposure to prolonged water stress and salt-coated soil left by high evaporation of water in the pulaka pits. Prolonged impacts on pulaka yield worsen traditional staple diets and leads to abandonment of pulaka cultivation and associated loss of traditional knowledge (Tekinene 2014; Paeniu 2018).

Prolonged lack of rainfall (related to La Niña conditions) contributed to the growth of invasive seaweed (Sargassum polycystum) species in Funafuti, Tuvalu in 2011 (N'Yeurt and Iese 2015). Tuvaluans also consider droughts as a punishment from God for sin or bad traditional leadership. Some islands replaced their chiefs because of the negative impacts of droughts:

People normally associate drought with bad omen. When drought struck, people tend to blame those in leadership for bringing bad omen. This traditional belief demands that leaders do step down and give way for new leaders with the hope of prosperity. (Paeniu 2018) 


\subsubsection{Variability in the timing, intensity and type of drought impacts across the PICTs}

The location of countries is an important influence on the timing and intensity of droughts (Kuleshov et al. 2014). For example, Samoa being in the south central Pacific experienced the impacts of El Niño and La Niña differently to, for example, Tuvalu which is further to the northwest. As shown in Table 1, drought conditions in Samoa associated with the 1997-1998 El Niño event were delayed due to excess rainfall from TC Ron and TC Tui earlier in 1998. In addition, although Tuvalu experienced drought during the weak 2011-2012 La Niña event, Samoa experienced a drought in 2010-2011 when ENSO was in its neutral phase. The impacts of droughts are severe in Samoa. For example, droughts in 1972, 1983, 1987 and 1997 triggered forest fires and destroyed $80 \%$ of food crops (Adriaens and Deelen 2012). The 2010-2011 drought event (a) reduced the Samoa Electrical Power Corporation generation from 35.9 to $10.8 \%$ (Adriaens and Deelen 2012); (b) resulted in Samoa Fire Services reporting 800 ha of forest destroyed by bushfires at Asau and Aopo (Kuleshov et al. 2014), the main habitat for the critically endangered tooth-pilled pigeon (Manumea) (Shuster n.d.); and (c) saw the Samoan government charter boats to supply about $97,000 \mathrm{~L}$ of water to the three main atoll islands of Tokelau which reported 10-20\% less water in their household tanks (OCHA 2011).

Other recorded impacts of droughts in PICTs include an increase in the incidence of pests and diseases such as parasitoids of Cyrtorhinus egg predator on aroids and increase of weevil (Cylas formicarius) that can cause losses of 60-100\% on sweet potato (Taylor et al. 2016). Droughts also affect the nutrient and chemical composition of some crops. For example, there is a significant increase of cyanogen in cassava during droughts (McGregor et al. 2016).

Droughts also affect the livelihood of people by destroying economic crops. The 19971998 El Niño event is a case in point where losses in the sugar cane industry were around \$US53 million, while other agriculture losses including livestock death amounted to \$US8 million. In the 1998 drought, Fiji lost approximately \$US63 million in the agriculture sector, and in an effort to combat this issue, the Fiji Government introduced the Crop Rehabilitation Programme (CPR) at a cost of \$US22 million (McKenzie et al. 2005; Iese et al. 2016).

There are also recorded larger scale impacts of historical droughts such as ecosystem changes in Rapa Nui (Wallin et al. 2005; Tromp and Dudgeon 2012), inter-island relocation in Tuvalu in 1600-1800 (Roberts 1958), tribal wars that led to internal displacements in Samoa "309 years ago" (Fepuleai et al. 2017) and British colonial resettlement of Gilbertese from Kiribati to Solomon Islands in the 1960s (Tabe 2019).

\subsection{Interactions between droughts and tropical cyclones in the PICTs-communities in a cycle of recovery mode}

ENSO events are associated with droughts in the PICTs, but ENSO events also shift the position of the ITCZ/SPCZ and, hence, increase the probability of tropical cyclones occurring within 6 to $10^{\circ}$ south of the SPCZ (Vincent et al. 2011; Howes et al. 2018; Magee et al. 2020). For this reason, the tropical cyclone tracks during the years corresponding to the case study drought events mentioned above were extracted from the Australia Bureau of Meteorology's (BOM's) Objective Tropical Cyclone Reanalysis database in order to analyse the interaction of droughts and tropical cyclones in selected countries (http:/www.bom.gov.au/cyclone/history/ tracks/beta/?region=sh).

There is a relationship between the occurrence and breaking of droughts and the close proximity of tropical cyclones to some south central-western Pacific Islands (Kuleshov et al. 
2014). Either delay in drought onset or ending of droughts were associated with the presence of tropical cyclones in the South Central-Western area. Tropical cyclones bring rainfall. For example, the droughts in 1982-1983 in Central and Southern Vanuatu ended at the same time TC Atu was close by. The 1998 drought in Northern Vanuatu and Central Vanuatu ended in March 1998 around the same time TC Zuman landed in the Northern Islands of Vanuatu and TC Yali was close to Central and Southern Vanuatu. The most severe meteorological drought according to SCOPIC for Fiji started during the neutral ENSO phase and later continued when 2015-2016 El Niño started. This drought ended in February 2016 at the same time TC Winston landed in Fiji with the impacts of TC Winston making recovery from drought conditions very difficult. The same drought behaviour was observed in Vanuatu during the El Niño of 2015-2016. Drought conditions started 5 months before TC Pam and continued about a month after TC Pam, coupling the impacts and delaying the effectiveness of recovery responses. Droughts followed tropical cyclones in Samoa in February 1998 after two tropical cyclones landed in January. Tonga also experienced a drought in February 1998 after TC Ron. This highlights one of the limitations of using meteorological drought indices as a proxy for agricultural drought, since rainfall associated with tropical cyclones can cause the meteorological drought index to suggest the drought is terminated when, from an agricultural perspective, it has not.

From a PICTs community and vulnerability perspective, understanding the succession between droughts-cyclones-droughts is important in terms of exposure and impacts. Sequential hazards may take place over 2-3 years, making it difficult for PICT communities to recover completely and causing communities to be "always in a recovery mode" (Iese et al. 2020). The drought-cyclone-drought succession contributes to severe impacts because of incomplete recovery from the previous disaster, compounding the vulnerability of communities (e.g. communities in Vanuatu were planting drought tolerant crops that were destroyed by TC Pam). When communities planted early maturing vegetable crops to help household recovery of food security and livelihoods after TC Pam, the following drought killed crops and further delayed the recovery of communities. This was also observed in Fiji after TC Winston. It is important to note that some El Niño events have ended but dry conditions continue because of entry into the normal dry season. This was observed in Northern Vanuatu in 1982-1983 and 2015-2016. Understanding the high exposure and vulnerability of communities to multiple and compound hazards (e.g. tropical cyclones bringing strong winds, high rainfall, floods, storm surges, salt water inundation (e.g. Chand et al. 2020) and droughts (lack of water, continuous high temperatures) coupled with slow-onset impacts of climate change such as sea level rise is crucial for risk reduction planning. This is the most important for coastal communities and lowlying islands (including atolls). The availability of other livelihood assets for drought resilience such as limited land for agriculture, reliance on wells (often brackish during droughts) for cooking and washing are severely reduced by rising sea level due to salt-water intrusion into wells and coastal erosion reducing arable lands (Thompson 2016).

\section{Future drought in the PICTs}

\subsection{What does the literature say about future droughts in the PICTs?}

The propagation of drought from meteorological to socioeconomic droughts (e.g. van Dijk et al. 2013) is influenced by many factors, including water infrastructure, farming practice, 
socio-cultural contexts and relevant supportive policy. The interactions between these factors are complex, and current understanding on how these interactions could change in the future is limited. For the PICTs, there is limited research into the impacts of future droughts and climate change on water quantity, water quality or agriculture productivity. This is mostly due to lack of observed data (Section 3.1) and limited modelling capacity which could mean such issues are currently too wicked a problem to resolve.

Existing literature generally estimates future drought impacts in the PICTs by extrapolating historical impacts in light of projected climate change (e.g. Lal 2011) or through sociallearning processes (e.g. Butler et al. 2014; Butler et al. 2020). Notwithstanding significant uncertainties associated with the climate model projections, national meteorological service across the PICTs is concerned that potential changes in drought will reduce local ability to alleviate water shortages and associated sanitation issues, reduce crop (e.g. cocoa) production and value and reduce copra export volume, and these impacts will be magnified if followed/ preceded by heavy rains, floods or tropical cyclones.

Future drought impacts in the PICTs have also been assessed using conceptual models (e.g. Mukheibir et al. 2017) or empirical models (e.g. White 2010; Loco et al. 2015). Loco et al. (2015) estimated the impact of projected climate change on the sustainable yield of fresh groundwater lenses in Kiribati and found that when droughts occur, the fresh groundwater lenses can contract considerably. For example, White et al. (2007) documented a reduction in thickness of $50 \%$ of the Bonriki lens in Kiribati. In addition, low-lying atoll islands are also vulnerable to inundation by seawater, which in turn can make groundwater saline and unfit for human consumption. Potential drought impacts in atoll nations such as Tuvalu, therefore, can be catastrophic. The combination of rising sea level risks, shrinking water table and deterioration of water quality has the potential to lead to relocation of communities (as has happened before in the 1960s (Tabe 2019)).

\subsection{Projections for future drought in the PICTs based on the Standardised Precipitation Index}

In this study, projections for future drought are defined based on the Standardised Precipitation Index (SPI) of McKee et al. (1993), a widely used index for determining meteorological drought, including in the Pacific (e.g. McGree et al. (2016), McGree et al. (2019) and SCOPIC). As per Kirono et al. (2020), the analyses used data from 34 climate model simulations of rainfall under historical (1900-2005) and future (Representative Concentration Pathway RCP8.5, 2006-2100) scenarios, which are available at the Coupled Model Intercomparison Project Phase 5 (CMIP5) and used in the IPCC Fifth Assessment Report (IPCC 2013) and the Australian Bureau of Meteorology and CSIRO (2014) study for the western tropical Pacific. Under RCP8.5 the projected range in mean temperature increase for 2081-2100 relative to $1986-2005$ is $2.6-4.8^{\circ} \mathrm{C}$ globally (IPCC 2013) and $2.0-4.0{ }^{\circ} \mathrm{C}$ for the western Pacific (Australian Bureau of Meteorology and CSIRO 2014).

Three drought metrics (i.e. duration, frequency and intensity) for a 20 -year baseline (reference) period and four future time periods are presented to characterise change in future drought relative to current (baseline) conditions. The baseline period is 20 years centred on 1995 (1986-2005, as used in IPCC (2013)), while the four future periods are centred on 2030 (2020-2039), 2050 (2040-2059), 2070 (2060-2079), and 2090 (2080-2099).

As per Kirono et al. (2020), a 12-month SPI time series is used to represent time required for water deficit conditions to affect various agricultural and hydrological systems (e.g. Szalai 
and Szinell 2000; Zargar et al. 2011). The SPI time series was calculated for both the modelled historical (1900-2005) and future (2006-2100) period, resulting in negative (positive) values for dry (wet) conditions. A drought event is defined when SPI is continuously negative for 3 months or more and reaches an SPI value of -1.0 or less at some time during the event. The event starts when the SPI first falls below zero and ends with the first positive value of SPI following a value of -1.0 or less. The associated maximum negative value reached in a given event can then be used to define three drought categories: moderate drought, severe drought and extreme drought. The thresholds for categorisation are moderate drought $(-1.5<\mathrm{SPI} \leq$ $-1.0)$, severe drought $(-2.0<\mathrm{SPI} \leq-1.5)$ and extreme drought $(\mathrm{SPI} \leq-2.0)$ (McKee et al. 1993).

The drought metrics within a period of interest (e.g. 1986-2005) were then calculated as:

- Drought frequency (DF): the number of droughts in a given period of interest.

- Drought duration (DD): the average length (in months) of drought events for the selected period.

- Drought intensity (DI): the average of cumulative SPI from all events for the selected period. The more negative the value the more intense the event.

As shown in Fig. 2, drought projections for the PICTs vary by country and by the drought category and metrics. However, these variations are smaller than the range of projections coming from the use of a multi-model ensemble. This is consistent with findings from global studies (e.g. Touma et al. 2015; Cook et al. 2018), regional studies elsewhere (e.g. Kirono et al. 2011; Tan et al. 2019; Kirono et al. 2020) and previous studies in the Pacific (Australian Bureau of Meteorology and CSIRO 2014).

Overall, droughts are projected to occur less often, become less intense and become shorter, except for in Samoa, Vanuatu and Tuvalu (Fig. 2). For Fiji, PNG and Tonga, the multi-model median shows significant decrease in the duration, frequency and intensity for most drought categories by the second half of the century. The range of projections are large (i.e. from increase to decrease), particularly for extreme droughts, but tend towards a decrease.

On the contrary, for Samoa, Tuvalu and Vanuatu, the decrease is apparent only for moderate and severe drought. For extreme drought, the multi-model median indicates little change, while the range of uncertainty, albeit large, is skewed towards an increase for most metrics. This implies that future drought events, when they occur, will tend to more often fall under what is currently classified as the extreme drought category rather than the moderate or severe drought category.

In general, the projected long-term changes to drought are consistent with the historical trends in droughts reported by McGree et al. (2016, 2019) (see also Section 3.1). McGree et al. (2016) used observed station data in the PICTs and found that historical trends were spatially heterogeneous and largely non-significant. More recently, McGree et al. (2019) reported nonsignificant sub-regional trends in the 12-month SPI over New Guinea Islands, North Papua New Guinea, Central Pacific, Southwest Pacific and Southeast SPCZ locations.

The projected trends for most of the drought metrics over most countries are also in accordance with the overall projected increase of the equatorial Pacific rainfall in a warmed climate (e.g. Australian Bureau of Meteorology and CSIRO 2014; Watanabe et al. 2014). The expected wetter conditions relate to the intensification of the South Pacific Convergence Zone (SPCZ) and the West Pacific monsoon due to increased atmospheric moisture content in a warming world. The tendency towards a future with drought events that are more extreme is also consistent with studies finding that rainfall variability over the equatorial Pacific is 
projected to increase under warmer climate conditions (e.g. Watanabe et al. 2014; Cai et al. 2014; Power et al. 2017).

When interpreting these results, it is important to note the weaknesses associated with climate model projections for the Pacific (Grose et al. 2014), In particular, as discussed in Section 3, natural climate variability (e.g. ENSO, IPO) plays an important in influencing the interannual to multidecadal variability of drought risk in the PICTs (e.g. McGree et al. 2016), but this relationship is not yet realistically simulated by climate models (see Section 5 for further discussion on this). One way to, at least partially, deal with this issue is to use multimodel ensemble (as we have done in this study) with the assumption being that the spread across the different climate models captures ENSO variability. The validity of this assumption is the topic of ongoing research (see Section 5 for further details).

\section{Knowledge gaps and recommendations for future work}

The main knowledge gaps associated with understanding and managing drought in the PICTs, along with recommendations for future work needed to address them, are the following:

- Lack of understanding into agricultural and hydrological droughts. Some data and research exists on meteorological droughts but there is no detailed information on the duration, frequency and intensity of agricultural or hydrological droughts in the Pacific Islands. To properly characterise drought and to successfully quantify and manage the environmental and socioeconomic impacts of drought, drought indicators should be developed that realistically capture how all the different types of drought evolve. This is challenging for many parts of the PICTs due to limited (or non-existent) ground-based hydrometeorological observations of important drought-related variables (e.g. precipitation, near-surface air temperature, wind speed, atmospheric water vapour, relative humidity, and atmospheric evaporative demand). Furthermore, the available observations are usually not sufficient to capture the true spatiotemporal variability of drought (e.g. Easterling 2013; Gibson et al. 2020; Askarimarnani et al. 2021) or the lag of months to years between rainfall deficits (i.e. meteorological drought) and the progressive depletion of surface, soil and groundwater stores (i.e. agricultural, ecological and hydrological drought) (e.g. van Dijk et al. 2013; Kiem et al. 2016). These realities require a paradigm shift that supplements ground-based point observations or interpolated grids with satellite remote sensing information about relevant hydrological and ecological processes (or other sector based indicators) that are linked to drought (e.g. AghaKouchak et al. 2015). First, however, research is required to assess the strengths and weaknesses of satellite remote sensing information in detecting and monitoring the different types of drought in the PICTs.

- Lack of quantification and attribution of historical drought trends and variability. Analysis is required to determine if and how droughts have changed in the past across the different PICTs (including better understanding into the role of SPCZ and its association with ENSO, IPO and droughts across the PICTs). This is important given the warming already experienced over the last few decades and the need to establish what, if any, impact that warming has had on drought behaviour (i.e. frequency, duration, magnitude) in the PICTs. Also required is a critical examination of model simulations of historical climate conditions to determine which climate models are likely to give the most credible information 


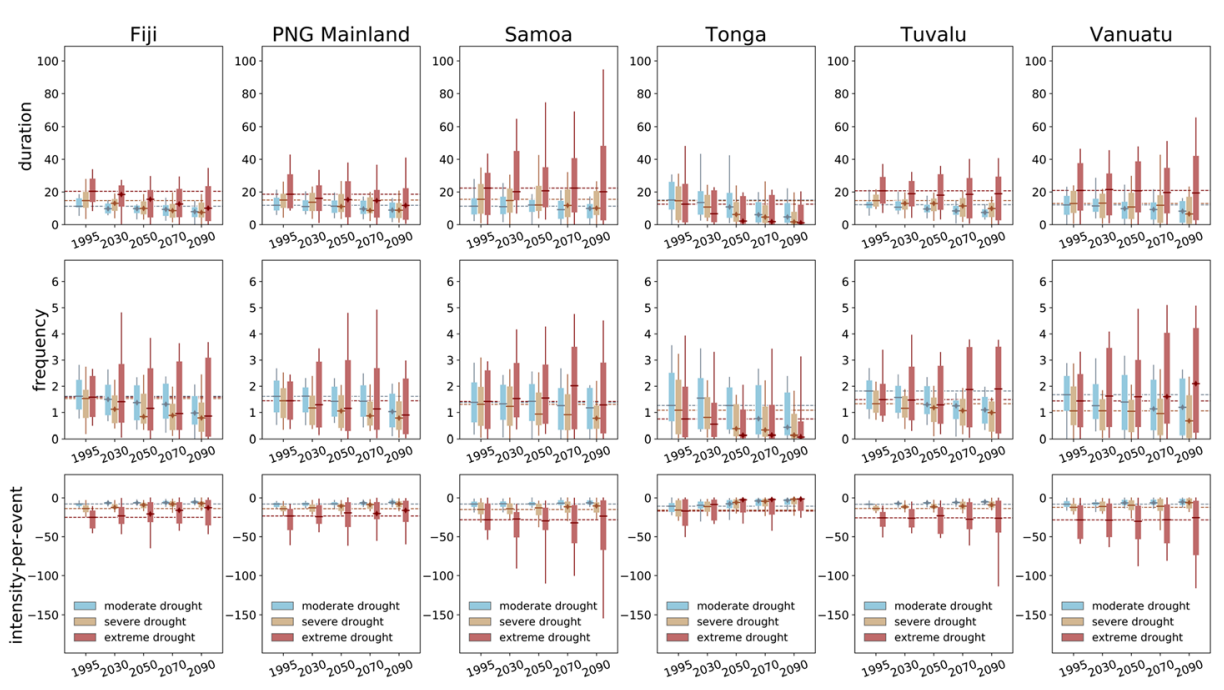

Figure 2 Regional (country) average of drought metrics for each drought category in the reference (20 years centred on 1995) and future (20-year periods centred on 2030, 2050, 2070, 2090) periods (drought duration is in months, frequency is in "number of events per period", while intensity is unitless). The multi-model ensemble is shown as median, 10th and 90th percentile (bars) and minimum and maximum values (whiskers). The dashedlines show the multi-model median for the baseline period for each category drought. The diamond symbols denote that the median metric at a given period in the future statistically differs (with $p<0.05$ ) to the mean metrics in the reference period (1995). For drought intensity, the more negative the value, the more intense the event

about the future (e.g. climate models that can realistically simulate historical changes to drought are more likely to realistically simulate future drought behaviour).

- Inadequate predictions/projections of drought start, duration, magnitude and spatial extent (as opposed to the current focus on just rainfall) with seasonal lead times. Predictions/ projections require understanding into, and realistically modelling of, the influence of multiple large-scale climate drivers on rainfall in the PICTs (e.g. To what extent do cold front systems bring drought breaking rainfall to southern Vanuatu, southern Fiji and Tonga?). Predictions/projections also require a better understanding of soil properties at small and large-scales to capture the soil moisture dynamics (agricultural drought) and the hydrologic connectivity within the system (hydrological drought). The drought predictions (and longer-term projections) also need to meet stakeholder requirements in terms of leadtime, skill/reliability and seasonality/timing (e.g. physical parameters that have longer lead-time need to be identified and imported into SCOPIC). For the longer-term drought projections in particular, it is especially important that the climate models producing those projections more realistically simulate the processes and impacts of natural climate variability (e.g. ENSO, IPO), especially at the local/regional scale, and how anthropogenic climate change will contribute to or alter that.

- Lack of understanding into the drought-cyclone-drought succession which has been identified as a critical component of the vulnerability of communities in the PICTs to drought. Drought recovery programs or adaptation options aimed at increasing drought resilience are often interrupted or destroyed by tropical cyclones. This is especially the case for coastal communities and low-lying islands (including atolls). Further research is needed to (i) better understand and quantify the drought-cyclone-drought succession, if/ how it has varied in the past, and if/how it is projected to change in the future and (ii) 
ensure that drought recovery programs and adaptation options aimed at increasing drought resilience consider and allow for the fact that in the PICTs these activities are likely to coincide with the impacts from one or more tropical cyclones.

- Lack of drought management strategies that recognise different parts of the PICTs are affected differently by the different types of droughts. Heterogeneity exists both between and within the different PICTs (e.g. the high islands have rivers, streams and groundwater so are affected by meteorological, agricultural and hydrological drought whereas the smaller islands and atolls rely exclusively on rainwater and therefore are only influenced by meteorological drought). Such location-specific impacts require location-specific drought management and adaptation strategies that are informed by both traditional and non-traditional knowledge. Research is required to identify and implement location-specific and fit-for-purposes drought management and adaptation strategies across the parts of the PICTs that are most vulnerable to drought. This includes:

- Reviewing and updating existing "standard operating procedures (SOPs)" used by National Meteorological Services to forecast, monitor and deal with drought (or establishing drought SOPs for the PICTs where none exist) to ensure the drought SOPs are consistent with international best practice.

- Developing decision support tools such as crop models that can simulate the impacts of drought on specific crops and agriculture systems in different agro-ecological zones. This information can then be used to identify and evaluate investments to improve agriculture adaptation so as to maximise resilience, productivity and sustainability.

- Developing/implementing early warning systems that improve the capacity of communities to forecast, prepare for and respond to drought events and thereby minimise social and economic impacts. This is a challenge in PICTs, and elsewhere, because the majority of early warning systems are established to predict and reduce the impacts of rapid-onset, short-lived climate-related disasters such as floods and cyclones.

- Development and validation of impact models that realistically simulate the location- and sector-specific impacts of drought in the PICTs. The impact models should be holistic such that environmental, economic, social and community impacts are considered in an integrated way.

- Lack of documentation and data on the impacts of drought in the PICTs in some of the sectors that are most vulnerable (e.g. water supply, health, tourism and agriculture). Therefore, it is important for future research, capacity building activities and other funding incentives to consider behavioural change such that drought impact reporting and awareness of drought is enhanced.

\section{Conclusion}

Successfully managing the impact of drought on society and the environment depends on the ability to successfully identify and characterise drought, in particular how the impacts of drought vary in different locations and different socioeconomic contexts. This is particularly important in the PICTs because the impacts of drought vary significantly depending on (i) the type of drought (e.g. meteorological drought compared with agricultural drought); (ii) the 
location (e.g. high islands versus atolls); (iii) socioeconomic conditions in the location affected by drought; and (iv) cultural attitudes towards the causes of drought (e.g. a punishment from God versus a natural process that is potentially predictable and something which can be managed).

For many locations within the PICTs, there is currently almost no ability to tell when a drought will begin or end, especially for droughts other than meteorological droughts. This is because monitoring, forecasting and managing drought in the PICTs is complex due to the variety of different ways droughts occur, and the diverse direct and indirect causes and consequences of drought, across the PICT region.

This paper uses a narrative analysis (i.e. a synthesis of anecdotal and qualitative information provided by officers from the national meteorological services) to demonstrate the diversity and spatial variability of drought impacts across the PICTs. The paper also quantifies, as best we can with existing climate model information, how drought is projected to change in the future for Pacific islands and atolls. Based on these two pieces of analysis, the major uncertainties and challenges relating to drought management in the Pacific are summarised along with some recommendations for how to address these challenges. It is hoped that recommendations identified are useful in guiding future research and investment towards minimising the negative impacts of droughts when they inevitably occur in the PICTs.

Open Access This article is licensed under a Creative Commons Attribution 4.0 International License, which permits use, sharing, adaptation, distribution and reproduction in any medium or format, as long as you give appropriate credit to the original author(s) and the source, provide a link to the Creative Commons licence, and indicate if changes were made. The images or other third party material in this article are included in the article's Creative Commons licence, unless indicated otherwise in a credit line to the material. If material is not included in the article's Creative Commons licence and your intended use is not permitted by statutory regulation or exceeds the permitted use, you will need to obtain permission directly from the copyright holder. To view a copy of this licence, visit http://creativecommons.org/licenses/by/4.0/.

\section{References}

Adriaens D, Deelen B (2012) Logistics Capacity Assessment: Independent State of Samoa. Technical Report

AghaKouchak A, Farahmand A, Melton FS, Teixeira J, Anderson MC, Wardlow BD, Hain CR (2015) Remote sensing of drought: progress, challenges and opportunities. Rev Geophys 53:452-480. https://doi.org/10. 1002/2014RG000456

Allen MG (2015) Framing food security in the Pacific Islands: empirical evidence from an island in the Western Pacific. Reg Environ Chang 15:1341-1353. https://doi.org/10.1007/s10113-014-0734-5

Askarimarnani SS, Kiem AS, Twomey CR (2021) Comparing the performance of drought indicators in Australia from 1900 to 2018. Int J Climatol 41:E912-E934. https://doi.org/10.1002/joc.6737

Australian Bureau of Meteorology, CSIRO (2014) Climate variability, extremes and change in the western tropical Pacific: new science and updated country reports. Pacific Australia Climate Change Science and Adaptation Planning Program, Melbourne

Barnett J (2011) Dangerous climate change in the Pacific Islands: food production and food security. Reg Environ Chang 11:229-237. https://doi.org/10.1007/s10113-010-0160-2

Barnett J, Campbell J (2010) Climate change and Small Island states: Power. Knowledge and the South Pacific, Earthscan, 218 pages

Below R, Grover-Kopec E, Dilley M (2007) Documenting drought-related disasters: a global reassessment. J Environ Dev 16:328-344. https://doi.org/10.1177/1070496507306222

Blauhut V, Gudmundsson L, Stahl K (2015) Towards pan-European drought risk maps: quantifying the link between drought indices and reported drought impacts. Environ Res Lett 10:14008-14017. https://doi.org/ $10.11088 / 11748-19326 / 14010 / 14001 / 014008$ 
Botterill LC, Cockfield G (eds) (2013) Drought, risk management, and policy: decision-making under uncertainty. Drought and Water Crises CRC Press, Taylor \& Francis Group, Boca Raton, pp 32742-33487

Bourke RM, Allen B, Lowe M (2016) Estimated impact of drought and frost on food supply in rural PNG in 2015. Development Policy Centre, Policy Bri(October), 9

Butler JRA, Skewes T, Mitchell D, Pontio M, Hills T (2014) Stakeholder perceptions of ecosystem service declines in Milne Bay, Papua New Guinea: is human population a more critical driver than climate change? Mar Policy 46:1-13. https://doi.org/10.1016/j.marpol.2013.12.011

Butler JRA et al (2020) How feasible is the scaling-out of livelihood and food system adaptation in Asia-Pacific Islands? Front Sustain Food Syst 4:43. https://doi.org/10.3389/fsufs.2020.00043

Cai W et al (2012) More extreme swings of the South Pacific convergence zone due to greenhouse warming. Nature 488:365-369. https://doi.org/10.1038/nature11358

Cai W et al (2014) Increasing frequency of extreme El Niño events due to greenhouse warming. Nat Clim Chang 4:111-116. https://doi.org/10.1038/nclimate2100

Centre PND (2016) El Niño 2015/2016 Post Drought Assessment: report of the interagency post drought assessment in Papua New Guinea

Chand SS (2020) Climate change scenarios and projections for the Pacific. In: Kumar L (ed) Climate change and impacts in the Pacific. Springer International Publishing, Cham, pp 171-199. https://doi.org/10.1007/978-3030-32878-8_3

Chand SS, Dowdy A, Bell S, Tory K (2020) A review of South Pacific tropical cyclones: impacts of natural climate variability and climate change. In: Kumar L (ed) Climate change and impacts in the Pacific. Springer International Publishing, Cham, pp 251-273. https://doi.org/10.1007/978-3-030-32878-8_6

Cook BI, Mankin JS, Anchukaitis KJ (2018) Climate change and drought: from past to future. Curr Climate Change Reports 4:164-179. https://doi.org/10.1007/s40641-018-0093-2

CSIRO, Australian Bureau of Meteorology, Secretariat of the Pacific Regional Environment Programme (SPREP) (2015) Climate in the Pacific: a regional summary of new science and management tools. Pacific-Australia Climate Change Science and Adaptation Planning Program Summary Report, Melbourne

Deo RC (2011) On meteorological droughts in tropical Pacific Islands: time-series analysis of observed rainfall using Fiji as a case study. Meteorol Appl 18:171-180. https://doi.org/10.1002/met.216

Easterling DR (2013) Global data sets for analysis of climate extremes. In: AghaKouchak A, Easterling DR, Hsu $\mathrm{K}$, Schubert S, Sorooshian S (eds) Extremes in a changing climate, Water science and technology library, vol 65. Springer, Dordrecht, pp 347-361

Fepuleai A, Weber E, Németh K, Muliaina T, Iese V (2017) Eruption styles of Samoan volcanoes represented in tattooing, language and cultural activities of the indigenous people. Geoheritage 9:395-411. https://doi.org/ 10.1007/s12371-016-0204-1

Garner G, Van Loon AF, Prudhomme C, Hannah DM (2015) Hydroclimatology of extreme river flows. Freshw Biol 60:2461-2476. https://doi.org/10.1111/fwb.12667

Gibson AJ, Verdon-Kidd DC, Hancock GR, Willgoose G (2020) Catchment-scale drought: capturing the whole drought cycle using multiple indicators. Hydrol Earth Syst Sci 24:1985-2002. https://doi.org/10.5194/hess24-1985-2020

Goldberg WM (2018) An introduction to the tropical Pacific and types of Pacific Islands. In: The geography, Nature and History of the Tropical Pacific and its Islands. Springer International Publishing, Cham, pp 1-38. https://doi.org/10.1007/978-3-319-69532-7_1

Grose MR et al (2014) Assessment of the CMIP5 global climate model simulations of the western tropical Pacific climate system and comparison to CMIP3. Int J Climatol 34:3382-3399. https://doi.org/10.1002/joc.3916

Howes E, Birchenough S, Lincoln S (2018) Effects of climate change on $1.5^{\circ}$ temperature rise relevant to the Pacific Islands. PACIFIC MARINE CLIMATE CHANGE REPORT CARD Science Review, (June), 1-19 (https://reliefweb.int/sites/reliefweb.int/files/resources/12-1.5-degree-temperature-rise.pdf)

Iese V et al (2016) Community-based loss and damage assessment toolkit for the tourism and agricultural sectors. Pacific Centre for Environment and Sustainable Development, Fiji

Iese $\mathrm{V}$ et al (2018) Facing food security risks: the rise and rise of the sweet potato in the Pacific Islands. Global Food Sec 18:48-56. https://doi.org/10.1016/j.gfs.2018.07.004

Iese V et al (2020) Agriculture under a changing climate. In: Kumar L (ed) Climate change and impacts in the Pacific. Springer International Publishing, Cham, pp 323-357. https://doi.org/10.1007/978-3-030-32878-8_9

IPCC (2013) Contribution of Working Group I to the Fifth Assessment Report of the Intergovernmental Panel on Climate Change. In: Stocker TF, Qin D, Plattner G-K, Tignor M, Allen SK, Boschung J, Nauels A, Xia Y, Bex V, Midgley PM (eds) Climate change 2013: the physical science basis

Keremama M, Holland EA, Khan M, Hiriasia D, Tahani L (2019) Air temperature trends, variability and extremes across the Solomon Islands: 1951-2011. Pacific Dynam J Interdisciplin Res 3:15-31

Kiem AS, Franks SW (2004) Multi-decadal variability of drought risk - eastern Australia. Hydrol Process 18 : 2039-2050 
Kiem AS et al (2016) Natural hazards in Australia: droughts. Clim Chang 139:37-54. https://doi.org/10.1007/ s10584-10016-11798-10587

Kirono DGC, Kent DM, Hennessy KJ, Mpelasoka F (2011) Characteristics of Australian droughts under enhanced greenhouse conditions: results from 14 global climate models. J Arid Environ 75:566-575. https://doi.org/10.1016/j.jaridenv.2010.12.012

Kirono DGC, Round V, Heady C, Chiew FHS, Osbrough S (2020) Drought projections for Australia: updated results and analysis of model simulations. Weather Climate Extrem 30:100280. https://doi.org/10.1016/j. wace. 2020.100280

Kuleshov Y et al. (2014) Extreme weather and climate events and their impacts on island countries in the Western Pacific: cyclones, floods and droughts. Atmosph Climate Sci 4:803-818, doi:8https://doi.org/10. 4236/acs.2014.45071

Lal PN (2011) Climate change adaptation in the Pacific: making informed choices, A report prepared for the Australian Department of Climate Change and Energy Efficiency (DCCEE). IUCN, Suva

Lefale PF, Diamond HJ, Anderson CL (2018) Impacts of climate change on extreme events relevant to Pacific Islands, Pacific Marine Climate Change Report Card: Science Review, pp 51-57

Liberto TD (2016) Drought in the Pacific. Retrieved March 12, 2020, from https://www.climate.gov/newsfeatures/event-tracker/drought-pacific

Lloyd-Hughes B (2014) The impracticality of a universal drought definition. Theor Appl Climatol 117:607-611. https://doi.org/10.1007/s00704-013-1025-7

Loco A, Juliano L, Mataio M, Aroito M (2015) KIRIWATSAN water resources assessment, Beru Island, Kiribati. Secretariat of the Pacific Community, Suva

Magee AD, Lorrey AM, Kiem AS, Colyvas K (2020) A new island-scale tropical cyclone outlook for Southwest Pacific nations and territories. Sci Rep 10(1):11286. https://doi.org/10.1038/s41598-020-67646-7

Marango T (2015) Communities returning to abandoned water sources. Vanuatu Daily Post. October 2015

Masih I, Maskey S, Mussá FEF, Trambauer P (2014) A review of droughts on the African continent: a geospatial and long-term perspective. Hydrol Earth Syst Sci 18:3635-3649. https://doi.org/10.5194/hess-3618-36352014

McGree S, Schreider S, Kuleshov Y (2016) Trends and variability in droughts in the Pacific Islands and Northeast Australia. J Clim 29:8377-8397. https://doi.org/10.1175/jcli-d-16-0332.1

McGree S et al (2019) Recent changes in mean and extreme temperature and precipitation in the western Pacific Islands. J Clim 32:4919-4941. https://doi.org/10.1175/jcli-d-18-0748.1

McGregor A, Taylor M, Bourke RM, Lebot V (2016) Vulnerability of staple food crops to climate change. In: Taylor M, McGregor A, Dawson B (eds) Vulnerability of Pacific Island agriculture and forestry to climate change. Pacific Community (SPC), Noumea, pp 161-238

McKee TB, Doesken NJ, Kleist J (1993) The relationship of drought frequency and duration to time scales. 8th conference on applied climatology, Anaheim, 17-22 January 1993, 179-184

McKenzie E, Prasad B, Kaloumaira A (2005) Economic impacts of natural disasters on development in the Pacific. Tool one: guidelines for estimating the economic impact of natural disasters on development in the Pacific. Suva, Fiji

Mukheibir P, Boronyak-Vasco L, Alofa P (2017) Dynamic adaptive management pathways for drinking water security in Kiribati. In: Leal Filho W (ed) Climate change adaptation in Pacific countries: fostering resilience and improving the quality of life. Springer International Publishing, Cham, pp 287-301. https://doi.org/10. 1007/978-3-319-50094-2 17

Murphy BF, Power SB, McGree S (2014) The varied impacts of El Niño-southern oscillation on Pacific Island climates. J Clim 27:4015-4036. https://doi.org/10.1175/jcli-d-13-00130.1

N'Yeurt A, Iese V (2015) The proliferating brown alga Sargassum polycystum in Tuvalu, South Pacific: assessment of the bloom and applications to local agriculture and sustainable energy. J Appl Phycol 27: 2037-2045. https://doi.org/10.1007/s10811-014-0435-y

Nunn PD (2007) Climate, environment and society in the Pacific during the last millennium. In: Nunn PD (ed) Developments in Earth and Environmental Sciences, vol 6. Elsevier, p 302. https://doi.org/10.1016/S15719197(07)06001-6

OCHA Services (2011) Water shortage hits Tokelau. Originally published 4 Oct 2011. https://reliefweb.int/ report/tokelau/water-shortage-hits-tokelau.

OCHA (2015) El-Nino in the Pacific Special Humanitarian Bulletin, November. https://www. humanitarianresponse.info/sites/www.humanitarianresponse.info/files/documents/files/rop_hb_nov18.pdf.

Paeniu L (2018) Understanding and predicting drought in Tuvalu. MSc in Climate Change Thesis. Pacific Centre for Environment and Sustainable Development, The University of the South Pacific, Fiji

Parry S, Wilby RL, Prudhomme C, Wood PJ (2016) A systematic assessment of drought termination in the United Kingdom. Hydrol Earth Syst Sci Discuss 2016:1-33. https://doi.org/10.5194/hess-2015-5476 
Peterson TC et al (2013) Monitoring and understanding changes in heat waves, cold waves, floods, and droughts in the United States: state of knowledge. Bull Am Meteorol Soc 94:821-834. https://oi.org/10.1175/ BAMS-D-1112-00066.00061

Power SB, Delage FPD, Chung CTY, Ye H, Murphy BF (2017) Humans have already increased the risk of major disruptions to Pacific rainfall. Nat Commun 8:14368. https://doi.org/10.1038/ncomms14368

Roberts RG (1958) Te Atu Tuvalu: a short history of the Ellice Islands. J Polynes Soc 67:394-423

Roberts A (2015) Widespread water shortages. Vanuatu Daily Post October 2015

Salinger MJ, McGree S, Beucher F, Power SB, Delage F (2014) A new index for variations in the position of the South Pacific convergence zone 1910/11-2011/2012. Clim Dyn 43:881-892. https://doi.org/10.1007/ s00382-013-2035-y

Savage A, Bambrick H, Gallegos D (2021) Climate extremes constrain agency and long-term health: a qualitative case study in a Pacific Small Island developing state. Weather Climate Extrem 31:100293. https://doi.org/10. 1016/j.wace.2020.100293

Shuster TC (n.d) Important bird areas of Samoa. Birdlife International in partnership with Conservation International, $\mathrm{O}$ Le Siosiomaga Society Incorporated and the Ministry of Natural Resources and Environment. Technical Report

Sinclair P, Atumurirava F, Samuela J (2012) Rapid drought assessment Tuvalu 13 October - 8 November 2011: SOPAC technical report (PR38). Funafuti, Tuvalu.

Sisifa A, Taylor M, McGregor A, Fink A, Dawson B (2016) Pacific communities, agriculture and climate change. In: Taylor M, McGregor A, Dawson B (eds) Vulnerability of Pacific Island agriculture and forestry to climate change. Pacific Community (SPC), Noumea, pp 5-46

Szalai S, Szinell C (2000) Comparison of two drought indices for drought monitoring in Hungary - a case study. In: Vogt JV, Somma F (eds) Drought and drought mitigation in Europe. Springer Netherlands, Dordrecht, pp 161-166. https://doi.org/10.1007/978-94-015-9472-1 12

Tabe T (2019) Climate change migration and displacement: learning from past relocations in the Pacific. Sociol Sci 8:218

Tan ML, Juneng L, Tangang FT, Chan NW, Ngai ST (2019) Future hydro-meteorological drought of the Johor River basin, Malaysia, based on CORDEX-SEA projections. Hydrol Sci J 64:921-933. https://doi.org/10. $1080 / 02626667.2019 .1612901$

Taylor M et al (2016) Agriculture and climate change: an overview. In: Taylor M, Gregor AM, Dawson B (eds) Vulnerability of Pacific Island agriculture and forestry to climate change. Pacific Community (SPC), Noumea, pp 103-160

Tekinene M (2014) An assessment of the impacts of climate change on cultivated pulaka (Cyrtosperma chamissonis) in Tuvalu. University of the South Pacific, Fiji

Thompson A (2016) When the rains disappear, drought grips Pacific Islands. Retrieved March 12, 2020, from https://www.climatecentral.org/news/el-nino-drought-grips-pacific-islands-20317

Tigona RS, de Freitas CR (2012) Relationship between the southern oscillation and rainfall in Vanuatu. Weather Climate 32:43-50

Touma D, Ashfaq M, Nayak MA, Kao S-C, Diffenbaugh NS (2015) A multi-model and multi-index evaluation of drought characteristics in the 21st century. J Hydrol 526:196-207. https://doi.org/10.1016/j.jhydrol.2014. 12.011

Tromp M, Dudgeon JV (2012) Dietary microfossils from Rapa Nui dental calculus: does regional variability provide evidence for subsistence practices? In 8th international conference on Easter Island and the Pacific. Santa Rosa, Califonia

UNESCAP (2007) Regional implementation meeting for Asia and the Pacific for the sixteenth session of the Commission on Sustainable Development Backgroud Paper on Drought - an Assessment of Asian and Pacific Progress. Retrieved from https://sustainabledevelopment.un.org/content/documents/escap_drought. pdf

van Dijk AIJM et al (2013) The millennium drought in Southeast Australia (2001-2009): natural and human causes and implications for water resources, ecosystems, economy and society. Water Resour Res 49:1-18

Van Loon AF (2015) Hydrological drought explained. Wires Water 2:359-392. https://doi.org/10.1002/wat1002. 1085

Van Loon AF et al (2016a) Drought in the Anthropocene. Nat Geosci 9:89-91. https://doi.org/10.1038/ngeo2646

Van Loon AF et al (2016b) Drought in a human-modified world: reframing drought definitions, understanding and analysis approaches. Hydrol Earth Syst Sci Discuss 2016:1-34. https://doi.org/10.5194/hess-2016-5251

Vance TR, Roberts JL, Plummer CT, Kiem AS, van Ommen TD (2015) Interdecadal Pacific variability and eastern Australian mega-droughts over the last millennium. Geophys Res Lett 42:129-137, doi:1https://oi. org/10.1002/2014GL062447 
Vincent EM, Lengaigne M, Menkes CE, Jourdain NC, Marchesiello P, Madec G (2011) Interannual variability of the South Pacific Convergence Zone and implications for tropical cyclone genesis. Clim Dyn 36:1881-1896. https://doi.org/10.1007/s00382-009-0716-3

Wairiu M, Lal M, Iese V (2012) Climate change implications for crop production in Pacific Islands region. In: Aladjadjiyan AP (ed) Food production - approaches, challenges and tasks. InTech, Food production approaches, challenges and tasks, pp 67-86. https://doi.org/10.5772/1870

Wallin P, Stevenson C, Ladefoged T (2005) Sweet potato production on Rapa Nui. In: Ballard C, Brown P, Bourke RM, Harwood T (eds) The sweet potato in Oceania: a reappraisal. University of Pittsburgh and University of Sydney, Sydney and Pittsburgh, pp 85-88

Watanabe M, Kamae Y, Kimoto M (2014) Robust increase of the equatorial Pacific rainfall and its variability in a warmed climate. Geophys Res Lett 41:3227-3232. https://doi.org/10.1002/2014g1059692

White I (2010) Tarawa water master plan: Te ran, groundwater. Goevernment of the Republic of Kiribati. Technical Report

White I, Falkland T, Metutera T, Metai E, Overmars M, Perez P, Dray A (2007) Climatic and human influences on groundwater in low atolls. Vadose Zone J 6:581-590. https://doi.org/10.2136/vzj2006.0092

Wilhite DA, Svoboda M, Hayes M (2007) Understanding the complex impacts of drought: a key to enhancing drought mitigation and preparedness. Water Resour Manag 21:763-774

Willie G (2015) Food shortage, drought endanger communities Vanuatu Daily Post September 2015

Zargar A, Sadiq R, Naser B, Khan FI (2011) A review of drought indices. Environ Rev 19:333-349. https://doi. org/10.1139/a11-013

Publisher's note Springer Nature remains neutral with regard to jurisdictional claims in published maps and institutional affiliations.

\title{
Affiliations
}

Viliamu lese ${ }^{1} \cdot$ Anthony S. Kiem $^{2} \cdot$ Azarel Mariner $^{3} \cdot$ Philip Malsale $^{3} \cdot$ Tile Tofaeono $^{3}$. Dewi G.C. Kirono ${ }^{4}$ - Vanessa Round ${ }^{4} \cdot$ Craig Heady $^{4} \cdot$ Robson Tigona $^{5}$ - Filipe Veisa ${ }^{5}$. Kisolel Posanau ${ }^{6}$. Faapisa Aiono ${ }^{7}$ - Alick Haruhiru ${ }^{8}$ - Arieta Daphne ${ }^{9}$. Vaiola Vainikolo $^{10} \cdot$ Nikotemo lona $^{11}$

\author{
Azarel Mariner \\ azarelm@sprep.org \\ Philip Malsale \\ philipm@sprep.org \\ Tile Tofaeono \\ tilet@sprep.org \\ Dewi G.C. Kirono \\ dewi.kirono@csiro.au \\ Vanessa Round \\ vanessa.round@csiro.au \\ Craig Heady \\ craig.heady@csiro.au \\ Robson Tigona \\ Robson.tigona@usp.ac.fj \\ Filipe Veisa \\ Filipe.veisa@usp.ac.fj \\ Kisolel Posanau \\ solel.posanau@gmail.com
}


Faapisa Aiono

faapisa.aiono@mnre.gov.ws

Alick Haruhiru

a.haruhiru@met.gov.sb

Arieta Daphne

Arieta.Daphne@met.gov.fj

Vaiola Vainikolo

vaiolap@met.gov.to

Nikotemo Iona

niko.iona@gmail.com

1 Climate Change, Food Security, Disaster Risk Management, Pacific Centre for Environment and Sustainable Development (PaCE-SD), The University of the South Pacific, Suva 3232828, Fiji Islands

2 Centre for Water, Climate and Land (CWCL), College of Engineering, Science and Environment (CESE), University of Newcastle, Callaghan, NSW 2308, Australia

3 Secretariat of the Pacific Regional Environment (SPREP), Apia, Samoa

4 CSIRO Climate Science Centre, Oceans and Atmosphere, Melbourne, Australia

5 Pacific Centre for Environment and Sustainable Development, The University of the South Pacific, Suva, Fiji Islands

6 Papua New Guinea National Weather Service, Port Moresby, Papua New Guinea

7 Samoa Meteorology Division, Apia, Samoa

8 Solomon Islands Meteorological Services, Honiara, Solomon Islands

$9 \quad$ Fiji Meteorological Services, Nadi, Fiji

10 Tonga Meteorological Services, Nuku'alofa, Tonga

11 Tuvalu Meteorological Services, Funafuti, Tuvalu 